IMPLEMENTASI ISLAM INA-INA PEDAGANG KELILING DI KECAMATAN PALU BARAT KOTA PALU

\title{
Samsinas Samsinas
}

Institut Agama Islam Negeri Palu

Email: samsinas29@yahoo.co.id

\section{Abstract:}

This paper deals with the societal structure where ina-ina live, and its influences toward their religious life, which in turn, gives impacts on their social interaction either in family or social environment. Sociologically, female peddlers (ina-ina) are part of Muslim community in their village. They are responsible for their family and society, establishing social harmony. Although female peddlers are economically poor, they do not want to be burden for the governnent and other people. Their religious commitment becomes a basis of power to survive, living a positif live for the future of their family especially their children. They recognize that this life is a mandate and which should be lived with pleasure. The factors that influence ina-ina female peddlers in such vilages as Tipo, Loli and Kanuna, include economic, social, cultural, educational, political and religious. It is these factors that define ina-ina female peddlers' religious life.

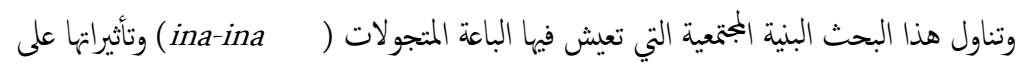

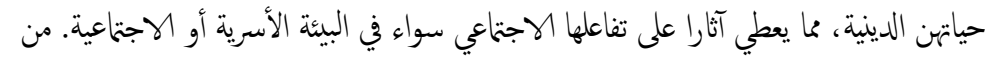

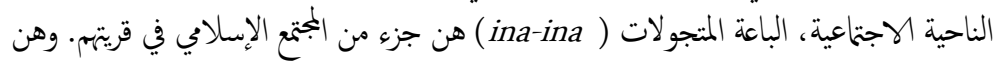

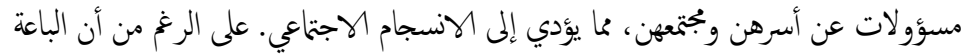

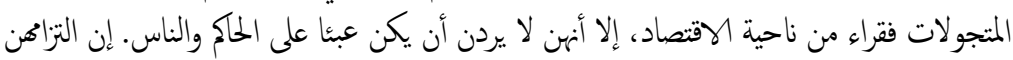

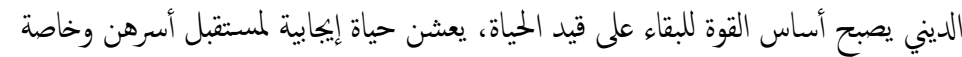

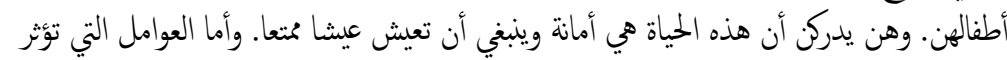

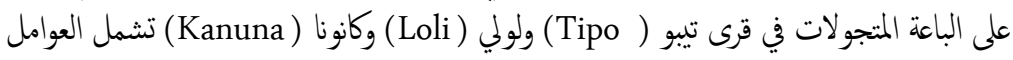


Samsinas, Implementasi Islam Ina-ina Pedagang....

$$
\text { الاقتصادية والاجتماعية والثقافية والنعلمية والسياسية والدينية. هذه العوامل هي التي تحدد الحياة }
$$

Kata Kunci: implementasi, Islam, ina-ina pedagang keliling

\section{A. Pendahuluan}

Manusia secara fitrah merupakan makhluk budaya, dimana ia diciptakan dengan akal dan hati. Akal berfungsi untuk memikirkan, menimbang dan memutuskan yang terbaik untuk manusia kemudian menciptakan wujud hasil kerja akalnya untuk digunakan sesuai kebutuhan manusia itu sendiri. Hati berfungsi untuk memahami, memaknai dan membedakan baik dan buruk bagi kehidupan manusia. Maka wujud cipta hati adalah rasa, karsa dan keindahan. Wujud ketiganya dapat berupa tata krama, karya seni maupun pola hubungan transenden dengan Sang Pencipta. Dengan demikian manusia memikirkan, merasakan dan menjalani seluruh aspek kehidupan berdasarkan kerja akal dan hatinya. Hal ini merupakan kompetensi dasar spiritual manusia yang dapat diakumulasi dan disempurnakan dengan norma dan nilai-nilai agama.

Sejak awal terciptanya manusia selalu didekatkan dengan Allah. Bahkan pada masyarakat seprimitif apapun, ketika anaknya lahir juga akan selalu dikaitkan dengan hal-hal mistik sebagai bentuk hubungan trasendental (vertikal) antara makhluk dengan Tuhan Maha Pencipta. Demikian pula yang tergambar dalam keseharian manusia.

Secara normatif, Islam menjunjung tinggi hak (fitrah) manusia. Sebagaimana Alqurān surah ar-R- m (30) ayat 30, menyebutkan;

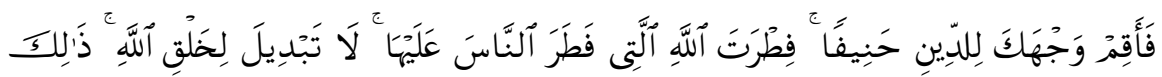

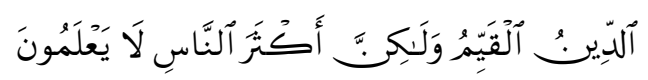




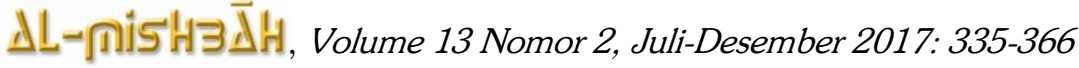

Terjemahnya:

"Maka hadapkanlah wajahmu kepada agama hanif, yang mana fitrah Allah (Agama) itu disesuaikan dengan fitrah manusia". ${ }^{1}$

Berdasarkan ayat diatas menunjukkan bahwa, agama tidak harus bertentangan dengan akal pikiran dan hati nurani manusia. Dengan demikian, Islam sebagai agama dakwah harus lebih banyak menyentuh aspek fitrah manusia dengan konsep dasar tauhid, syariat dan akhlak yang didalamnya mengandung nilai-nilai spiritual yang universal, humanis serta kemerdekan individu dan komunitas baik dalam menegakkan amar ma'ruf nahy munkar maupun dalam menjalani kehidupan sehari-hari dengan kebajikan.

Sehubungan dengan itu, di Indonesia konsep tauhid seperti ini sudah sangat dikenal oleh mayoritas muslim, sehingga ina-ina tidak hanya dapat hidup dalam keragaman karakter, budaya dan agama, tetapi juga dapat menjalani kehidupan duniawi dan ukhrawi secara bersamaan. Seorang muslim melakukan jual beli, atau kegiatan mu'amalah lainnya sebagai konsekwensi memenuhi kebutuhan duniawi tetapi juga sekaligus dapat memenuhi kebutuhan ukhrawi jika kegiatan itu dibangun dengan niat karena Allah, untuk tujuan yang benar dan dijalankan dengan caracara yang benar sesuai syariat Islam. Kemudian mensyukuri apa yang sudah diperoleh, mengeluarkan zakatnya dan berbagi jika berlebih. Hal yang sama dapat dilakukan dalam aspek kehidupan lainnya.

Secara realita, kegiatan mu'amalah seperti ini tidak hanya dapat dilakukan oleh kaum laki-laki, tetapi juga oleh kaum perempuan. Selain 2010), h. 150

${ }^{1}$ Departemen Agama RI, Alqurān dan Terjemahnya, (Bandung: Fokus Media, 
Samsinas, Implementasi Islam Ina-ina Pedagang....

karena tuntutan kemandirian sebagai manusia normal, tapi juga karena tuntutan keadaan ekonomi keluarga, terutama pada ina-ina yang diamanatkan tanggungjawab untuk menanggung beban keluarga, baik sebagai orang tua bagi anak-anaknya, istri bagi suami, suami bagi istrinya maupun saudara bagi saudaranya yang lain, dimana orang-orang yang ina-ina tanggung (bantu) adalah yang secara fisik ataupun secara mentalitas tidak berdaya untuk mencari nafkah dalam memenuhi kebutuhan diri sendiri maupun keluargannya.

Realitas ini masyarakat menunjukkan bahwa perempuan melakukan kegiatan jual beli atau perdagangan bukanlah masalah baru di dunia muslim, Islam masuk di Indonesia justru telah diperkenalkan oleh para wali dan para pedagang dari Arab dan Gujarat (India), ina-ina berdakwah sambil berdagang, sehingga antara kegiatan beradagang dan kegiatan keberagamaan menjadi satu kesatuan.

Demikian pula yang dilakukan oleh para dai yang sampai di Kota Palu, sebab berdasarkan realitas muslim Kota Palu awal didominasi oleh pedagang Arab dan India yang kemudian kawin mawin dengan masyarakat lokal dan ditambah lagi dengan transimigran dari komunitas suku lain seperti Bugis, Makasar, Gorontalo, Jawa, Padang, Lombok dan lainnya yang sudah lebih dulu menerima Islam didaerah asal sebelum pindah ke Kota Palu.

Bersamaan dengan berjalannya waktu, kemampuan berdakwah dan kemampuan berdagang komunitas Arab dan suku-suku transimigran lainnya justru mendomonasi masyarakat pribumi atau suku Kaili yang merupakan suku masyarakat lokal, akibatnya banyak diantara ina-ina memilih menjadi pedagang kecil, salah satu profesi masyarakat lokal adalah menjadi pedagang keliling yang menjajakan hasil alam dan hasil 
perkebunannya disekitar kota Palu dan atau kecamatan Palu Barat dengan cara memikul (barang-barang dagangannya) dan berjalan kaki dari pagi hari sampai sore hari. Sebuah pekerjaan yang sangat berat.

Pertanyaannya adalah bagaimana dengan kehidupan keagamaan ina-ina pedagang keliling dalam keseharian ina-ina baik pada saat ina-ina berjualan maupun ketika dirumah? Tentu saja ina-ina yang penulis maksud dalam penelitian ini adalah ina-ina yang beragama Islam (muslimah). Sebab dalam pengamatan awal penulis hampir tidak pernah terlihat ina-ina istrahat untuk sholat, meskipun ina-ina berada disekitar masjid. Sementara ina-ina keluar dari rumah sejak pagi hingga sore menjelang maghrib artinya bisa jadi ina-ina sampai dirumah pun sudah masuk waktu isya karena ina-ina pulang dengan berjalan kaki.

Disisi lain, konsep sosiologi Islam memandang bahwa keyakinan (terhadap agama Islam) menjadi dasar inspirasi bagi kepentingan berinteraksi, bersosialisasi dan beraktifitas. Termasuk didalamnya dalam memenuhi kebutuhan ekonomi keluarga. Selanjutnya, agama dapat disebut sebagai institusi yang mengatur kehidupan muslim dalam melakukan hubungan transendental kepada Sang Khalik dan juga dalam berinteraksi terhadap sesama muslim atau umat lainnya. Agama menghubungkan antara masalah duniawi dan ukhrawi, antara pemenuhan kebutuhan ekonomi dengan pemenuhan kebutuhan rohani sekaligus sehingga keduanya dapat dijalani secara seimbang untuk kebahagiaan lahir batin manusia itu sendiri.

Oleh karena itu data penelitian ini akan dianalisis dengan menggunakan pendekatan sosiologi Islam. Yakni melihat hubungan (interaksi) ina-ina dengan agama Islam yang ina-ina anut, dan implementasi hubungan itu dalam pola perilaku keagamaan ina-ina 
Samsinas, Implementasi Islam Ina-ina Pedagang....

dalam kehidupannya sehari-hari seperti dalam hubungan sosial, mencari nafkah (memenuhi kebutuhan ekonomi) dan lain sebagainya.

\section{B. Pendekatan Penelitian}

Penelitian ini menggunakan pendekatan kualititatif dengan pendekatan analisis sosiologi Islam. Yakni melihat struktur masyarakat dimana ina-ina tinggal dan pengaruhnya terhadap kehidupan beragamanya dan bagaimana kehidupan beragama ini memberi pengaruh terhadap hubungan sosial, baik dilingkungan keluarga maupun sosial. Berkaitan dengan itu, peneliti menggunakan beberapa teknik pengumpulan data yakni, wawancara, pengamatan, dan dokumentasi. Hasilnya diolah dan dianalisis sehingga menjamin keakuratan dan kevalidan data.

\section{Tinjauan Teoritis}

1. Ina-ina dan kehidupan beragama

a. Pengertian Ina-ina

Dalam referensi bahasa Kaili, ina ${ }^{2}$ adalah sebutan bagi seorang perempuan yang telah melahirkan yang dalam bahasa Indonesia disebut "ibu". Kebanyakan ina dinisbatkan kepada ibu-ibu yang berada atau berdomisili dipinggir kota Palu termasuk yang berada di wilayah Kecamatan Palu Barat. Sementara bagi ibu-ibu yang sudah tinggal di tengah Kota Palu umumnya dipanggil "mama" oleh anak-anaknya kerena ina-ina telah mengalami akulturasi dengan budaya masyarakat lain. Disisi lain kehadiran ina-ina ditengah masyarakat Kota selalu menunjukkan ciri

${ }^{2}$ https://capunktogel86.wordpress.com/arti-bahasa-kaili// diakses tanggal 6 Juni 2015 
khas yang unik, sehingga ketika melihatnya, orang-orang pun spontan memanggil dengan ina.

Ina, sebagaimana umumnya ibu, memiliki tanggungjawab dan peran dalam keluarga. Senantiasa menjalankan fungsi sebagai ibu bagi anak-anaknya atau pun keluarga yang membutuhkan uluran tangannya. Dalam rangka menjalankan fungsi itu maka salah satu peran yang biasa dijalani adalah mencari nafkah bagi keluarganya.

\section{b. Kehidupan Keberagamaan}

\section{1) Agama}

Agama merupakan sebuah koleksi terorganisir dari sebuah keyakinan, pandangan dunia dan sistem budaya yang menghubungkan orang-orang dengan tatanan kehidupan. Begitu banyak agama yang memiliki narasi, simbol dan sejarah suci yang ditujukan untuk menjelaskan makna hidup dan / atau menjelaskan alam semesta atau asal usul dari kehidupan. Meyakini sebagai keyakinan ina-ina tentang sifat sifat manusia, hukum agama atau gaya hidup yang lebih disukai. Menurut beberapa perkiraan, ada sekitar 4.200 agama di seluruh dunia. ${ }^{3}$

Praktik keagamaan juga mencakup rangkaian ritual penyembahan dan kemanusiaan, dakwah, seni dan pengorbanan, serta pelayanan terhadap kebutuhan masyarakat. Secara umum, agama merupakan institusi yang mengatur tentang kehidupan rohani manusia. Sebab manusia memiliki kemampuan yang terbatas dalam hal kesadaran transendental tentang sesuatu yang luar biasa di luar dari diri dan kemampuannya. Sesuatu yang luar biasa itu tentu berasal dari sumber

\footnotetext{
${ }^{3}$ Aris Kurniawan, http://www.gurupendidikan.com/3-pengertian-agama-menurutpara-ahli-keagamaan, diakses tanggal 20 September 2016
} 
Samsinas, Implementasi Islam Ina-ina Pedagang....

yang luar biasa juga. Dan sumber yang luar biasa dinamai macam-macam sesuai dengan bahasa manusia. Misalnya Tuhan dan sifat-Nya seperti Maha Kuasa, dan lain-lain.

Beberapa ahli membagi agama baik sebagai agama universal yang mencari penerimaan di seluruh dunia dan secara aktif mencari anggota baru, etnis atau agama diartikan dengan kelompok etnis tertentu dan tidak mencari orang baru untuk bertobat dari agamanya. Lainnya menolak perbedaan, menunjukkan bahwa semua praktek agama, apa pun ina-ina asalkan berfilosofis.

Pada abad ke-19 dan abad ke-20, praktek akademik dari perbandingan agama membagi keyakinan agama ke dalam kategori yang diartikan secara filosofis disebut "agama-agama dunia". Tetapi, beberapa sarjana baru-baru ini menyatakan bahwa tidak semua jenis agama harus dipisahkan oleh filosofi dan eksklusif, lebih jauh lagi bahwa utilitas menganggap praktek untuk filsafat tertentu, atau bahkan merujuk pada praktek-praktek keagamaan tertentu, sosial di alam dan tidak budaya, politik, yang terbatas.

Ada beberapa akademisi yang mempelajari tentang subjek yang membagi agama menjadi tiga kategori, yakni agama-agama dunia, sebuah istilah yang mengacu pada yang transkultural; dan agama pribumi, yang mengacu pada yang lebih kecil, budaya-tertentu atau kelompok agama-negara tertentu, serta gerakan keagamaan baru, yang mengarah pada agama baru ini dikembangkan.

2) Fungsi Agama

- Sumber kehidupan untuk individu maupun kelompok

- Hubungan menyesuaikan prosedur manusia dengan Tuhan dan manusia dengan manusia. 


\section{$\Delta$ L-nis $H 3 \bar{d}$ H, Volume 13 Nomor 2, Juli-Desember 2017: 335-366}

- Persyaratan prinsip benar atau salah

- Pedoman mengungkapkan rasa kebersamaan

- Pedoman merasa percaya diri adanya pedoman

- Estetika pengungkapan (kecantikan)

- Pedoman untuk rekreasi dan hiburan

- Memberikan identitas kepada orang-orang sebagai orang beragama. ${ }^{4}$

\section{3). Unsur-Unsur Agama}

Menurut Keller, Calhoun dan Leight, agama memiliki beberapa unsur pokok:

- Keyakinan agama, yang merupakan prinsip yang dianggap benar tanpa keraguan

- Simbol-simbol keagamaan, yaitu identitas agama yang dianut masyarakat.

- Praktik keagamaan, hubungan vertikal antara manusia dengan Tuhan, dan hubungan horizontal atau hubungan antarumat beragama sesuai dengan ajaran agama.

- Pengalaman religius, berbagai bentuk pengalaman keagamaan yang dihadapi oleh penganut pribadi.

- Orang yang religius, para pengikut agama. ${ }^{5}$

${ }^{4}$ Aris Kurniawan, http://www.gurupendidikan.com/3-pengertian-agama-menurutpara-ahli-keagamaan, diakses tanggal 20 September 2016

${ }^{5}$ Ibid. 
Samsinas, Implementasi Islam Ina-ina Pedagang....

4) Keberagamaan

Keberagamaan merupakan penggalan kata agama yang diberi imbuhan ke, ber dan an. Kata beragama sendiri berarti "memeluk" (menjalankan) agama. Menurut Porwadarminta, kata agama diartikan sebagai segenap kepercayaan (kepada Tuhan, dewa dan sebagainya), serta ajaran kebaktian dan kewajiban yang bertalian dengan kepercayaan itu. ${ }^{6}$ Sedang Keberagamaan mempunyai arti cara atau sikap seseorang dalam memeluk (menjalankan) agama yang dipeluk atau dianutnya. ${ }^{7}$ Agama yang dimaksudkan disini adalah agama Islam yang oleh Alqurān 8

Roland Robertson ${ }^{9}$ mengatakan, keberagamaan itu memiliki beberapa dimensi antara lain;

a) Dimensi Ideologi

Yakni dimensi dimana seseorang yang beragama berpegang teguh pada pandangan teologi tertentu dan mengakuinya sebagai perangkat kebenaran. Eksistensi dimensi ini bervariasi tidak hanya dalam agama-agama tetapi juga dalam tradisi.

${ }^{6}$ Poerwadarminta, Kamus Umum Bahasa Indonesia, (Jakarta: Balai Pustaka, 1978), h. 19.

${ }^{7}$ Ibid., h. 20.

${ }^{8}$ QS. Ali Imran (3): 19; "Sesungguhnya agama yang paling mulia di Sisi Allah adalah Islam". Lihat, Departemen Agama RI, Alqurān Terjemahnya, (Bandung: CV. Fokusmedia, 2010), 52

9 Roland Robertson, Agama dalam Analisa dan Interpretasi Sosiologis, Diterjemahkan oleh Syaifuddin, (Jakarta: Raja Grafindo Persada, 1993), 275-279 
b) Dimensi Ritual

Yakni Dimensi yang melahirkan berbagai macam ritus dan tindakan normatif beragama dan praktek-praktek suci. Oleh karena ini dimensi ini disebut dengan dimensi peradaban.

c) Dimensi Pengalaman

Yaitu dimensi yang berkaitan dengan pengalaman keagamaan, perasaan-perasaan, persepsi-persepsi dan sensasi-sensasi yang dialami seseorang sebagai kepuasan batin.

d) Dimensi Penghayatan

e) Dimensi Pengetahuan (ilmu)

Yaitu dimensi yang berkaitan dengan agama sebagai pengetahuan. Dalam Islam dibagi dalam beberapa dimensi lagi, antara lain; syari'ah, aqidah dan akhlak; syari'ah, tarekat dan ma'rifat; Iman, Islam dan Ihsan. ${ }^{10}$

f) Dimensi Sosial Keberagamaan

C.G. Glock dan R. Stark dalam bukunya "American Peaty: The Nature of Religion Commitmen" menyebut ada lima dimensi Agama dalam diri manusia yakni dimensi keyakinan (ideology), dimensi peribadatan dan praktek keagamaan (ritualistic), dimensi penghayatan (experensial), dimensi pengamalan (konsekwensial), dan dimensi pengetahuan agama (intelectual). ${ }^{11}$

Terkait dengan penelitian ini, salah satu dimensi yang tidak disebutkan diatas adalah dimensi perilaku sosial keagamaan yakni perilaku yang didasarkan agama. Namun pada aspek atau dimensi

10 Ibid.

11 Djamauddin Ancok, Fuat Nashori Suroro, Psykologi Islam (Yogyakarta: Pustaka Pelajar, 1995), 77 
Samsinas, Implementasi Islam Ina-ina Pedagang....

pengamalan (konsekwensial) adalah konsekwensi keyakinan berupa pengamalan perintah atau ajaran Tuhan yang terpatron, baik terkait hubungan transendental dengan Tuhan maupun dengan sesama manusia baik dalam kaitan dengan pemenuhan kebutuhan rohani maupun kebutuhan jasmani atau duniawi. Efek kemantapan keberagamaan menumbuhkan etos kerja, kepedulian sosial, dan hubungan interpersonal seperti tanggung jawab memenuhi kebutuhan keluarga dengan amanah dan kemuliaan.

Dalam perspektif Islam, kehidupan keberagamaan harus dilakukan secara komperehensif, sebagaimana disebutkan dalam surah Al-Baqarah (2): $208^{12}$;

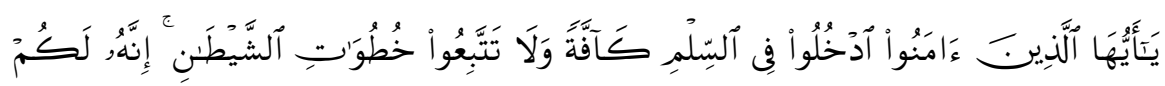

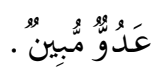

Terjemahnya;

"Hai orang-orang yang beriman, masuklah kamu ke dalam Islam keseluruhan, dan janganlah kamu turut langkah-langkah setan. Sesungguhnya setan itu musuh yang nyata bagimu".

Berdasarkan ayat ini, Allah memerintahkan kepada setiap muslim untuk menjalani Islam secara kaffah yang berarti dalam semua dimensi keberagamaan, sehingga dalam antara dimensi keyakinan memiliki hubungan dengan dimensi-dimensi yang lain termasuk dimensi sosial yang kemudian menggambarkan hubungan antara keberagamaan itu dengan perilaku sosial-ekonomi seseorang atau yang lainya.

${ }^{12}$ Kementerian Agama RI., Alqur'an dan..., 32 
Dalam Islam, keluasan keberagamaan menunjukkan kedalaman penghayatan atau kekuatan aqidah seseorang, kedalaman penghayatan dapat melahirkan intensitas dan konsistensi ritual pengamalan keagamaannya, kedalaman penghayatan dan konsistensi pengamalan agama akan berpengaruh pada sikap hidup dan hubungan sosial seorang muslim separti memiliki rasa tanggung jawab dan kepedulian terhadap keluarga dan masyarakat disekitarnya.

\section{Pendekatan Sosiologis Dalam Mengkaji Masyarakat Muslim}

Dalam studi Islam, pendekatan sosiologis sangat berguna sekali khususnya dalam mengkaji dan mengembangkan ajaran Islam yang berkaitan dengan masalah kemasyarakatan. Dalam Alquran, banyak ayatayat yang berkaitan dengan masalah-masalah sosial dan muamalah. ${ }^{13}$ Dalam kaitannya dengan itu konsep masyarakat dalam Islam juga menganut beberapa persamaan dan asas keseimbangan dalam masyarakat, yaitu keseimbangan antara hak dan kewajiban, keseimbangan antara individu dan masyarakat, keseimbangan antara hak individu dan kewajiban individu dan keseimbangan antara hak masyarakat dan kewajiban masyarakat. ${ }^{14}$

Pendekatan sosiologi seperti itu diperlukan sebab banyak hal yang dibicarakan agama hanya bisa dijelaskan melalui pendekatan sosiologi. Dari sisi lain terdapat pula signifikasi pendekatan Islam dalam sosiologi, salah satunya adalah dapat memahami fenomena sosial yang

${ }^{13}$ Lihat, QS: al-Baqarah:143, an-Nisa: 59, al-Anfal: 46, al-Maidah: 3, al-Hujarat: 13, Ali Imran: 103, al-Mukminun: 52, dll.

${ }^{14}$ Endang Saifuddin Ansari, Wawasan Islam, (Cet. IV; Jakarta: Raja Grafindo Persada, 1993), 64. 
Samsinas, Implementasi Islam Ina-ina Pedagang....

berkenaan dengan ibadah dan muamalat. Pentingnya pendekatan sosiologis dalam memahami agama dapat dipahami karena banyak sekali ajaran agama yang berkaitan dengan masalah sosial. Besarnya perhatian agama terhadap masalah sosial ini, selanjutnya mendorong agamawan memahami ilmu-ilmu sosial sebagai alat memahami agamanya.

Dalam bukunya yang berjudul Islam Alternatif, Jalaluddin Rahmat telah menunjukkan betapa besarnya perhatian agama yang dalam hal ini adalah Islam terhadap masalah sosial, dengan mengajukan lima alasan sebagai berikut: ${ }^{15}$ Pertama, dalam Alqur'an atau kitab hadits, proporsi terbesar kedua sumber hukum Islam itu berkenaan dengan urusan muamalah. Sedangkan menurut Ayatullah Khoemeini dalam bukunya al-Hukumah al-Islamiyah yang dikutip oleh Jalaluddin Rahmat dikemukakan bahwa perbandingan antara ayat-ayat ibadah dan ayat-ayat yang menyangkut kehidupan sosial adalah satu berbanding seratus. Artinya untuk satu ayat ibadah, ada seratus ayat muamalah (masalah sosial).

Kedua, bahwa ditekankannya masalah muamalah atau sosial dalam Islam ialah adanya kenyataan bahwa bila urusan ibadah bersamaan waktunya dengan urusan muamalah yang penting, maka ibadah boleh diperpendek atau ditangguhkan (bukan ditinggalkan) melainkan tetap dikerjakan sebagaimana mestinya.

Ketiga, bahwa ibadah yang mengandung segi kemasyarakatan diberi ganjaran lebih besar dari ibadah yang bersifat perseorangan. Karena itu shalat yang dilakukan secara berjamaah dinilai lebih tinggi

${ }^{15}$ Jalaluddin Rahmat, Islam Alternatef, (Bandung : Mizan, 1986), 48. 
nilainya daripada shalat yang dikerjakan sendirian dengan ukuran satu berbanding dua puluh tujuh derajat.

Keempat, dalam Islam terdapat ketentuan bila urusan ibadah dilakukan tidak sempurna atau batal, karena melanggar pantangan tertentu, maka kifaratnya ialah melakukan sesuatu yang berhubungan dengan masalah sosial. Bila puasa tidak mampu dilakukan misalnya, maka jalan keluarnya; dengan membayar fidyah dalam bentuk memberi makan bagi orang miskin.

Kelima, dalam Islam terdapat ajaran bahwa amal baik dalam bidang kemasyarakatan mendapat ganjaran lebih besar dari pada ibadah sunnah. ${ }^{16}$ Demikian sebaliknya sosiologi memiliki kontribusi dalam bidang kemasyarakatan terutama bagi orang yang berbuat amal baik akan mendapatkan status sosial yang lebih tinggi ditengah-tengah masyarakat, secara langsung hal ini berhubungan dengan sosiologi.

Berdasarkan kelima alasan diatas, maka melalui pendekatan sosiologis, agama akan dapat dipahami dengan mudah, karena agama itu sendiri diturunkan untuk kepentingan sosial atau asbab sosiologis. Sering sekali terjadi Alquran turun setelah ada kasus yang dihadapi oleh masyarakat sehingga turunnya ayat menjadi jawaban sekaligus solusi atas masalah yang ada.

Dalam Alquran dijumpai ayat-ayat berkenaan dengan hubungan manusia dengan manusia lainnya, sebab-sebab yang menyebabkan terjadinya kemakmuran suatu bangsa, dan sebab-sebab yang menyebabkan terjadinya kesengsaraan. Semua itu akan dapat dijelaskan

${ }^{16}$ Hussein Bahreisi, Hadits Bukhari-Muslim (Surabaya : Karya Utama, th), 160. 
Samsinas, Implementasi Islam Ina-ina Pedagang....

dengan baik apabila yang memahaminya melalui pendekatan sejarah, sosiologi atau sejarah-sosial ajaran agama itu diturunkan. ${ }^{17}$

a. Masyarakat Muslim

Menurut Kamus besar Bahasa Indonesia, masyarakat adalah sejumlah orang yang hidup bersama di suatu tempat, yang terikat oleh suatu kebudayaan yang ina-ina anggap sama. ${ }^{18}$ Hassan Shadily, mendefinisikan masyarakat adalah golongan besar atau kecil terdiri dari beberapa manusia, yang dengan atau karena sendirinya bertalian secara golongan dan pengaruh mempengaruhi satu sama lain. ${ }^{19}$ Sedangkan Hendropuspito, mengartikan masyarakat ialah kesatuan yang tetap dari orang-orang yang hidup di daerah tertentu dan bekerjasama dalam kelompok-kelompok, berdasarkan kebudayaan yang sama untuk mencapai kepentingan yang sama. ${ }^{20}$

Dari beberapa definisi tersebut, penulis menyimpulkan bahwa masyarakat adalah sejumlah orang yang hidup bersama di suatu tempat/daerah, saling mempengaruhi dan bekerja sama dalam kelompokkelompok, memiliki kebudayaan yang relatif sama, untuk mencapai kepentingan bersama. Tidak semua kelompok orang dapat disebut sebagai masyarakat.

\footnotetext{
${ }^{17}$ Abuddin Nata, Metodelogi Studi Islam, 42
}

${ }^{18}$ Peter Salim \& Yenny Salim, Kamus Bahasa Indonesia Kontemporer (Jakarta: Modern English Press, 1991), 945 1993), 47.

${ }^{19}$ Hassan Shadily, Sosiologi Untuk Masyarakat Indonesia, (Jakarta: Rineka Cipta,

${ }^{20}$ Hendropuspito, Sosiologi Sistemik, (Yogyakarta: Kanisius, 1989), 75. 


\section{$\Delta$-nis H 3 A H, Volume 13 Nomor 2, Juli-Desember 2017: 335-366}

Menurut Hendropuspito, ada beberapa ciri dari masyarakat, yaitu:

1. Memiliki wilayah dan batas yang jelas.

2. Merupakan satu kesatuan penduduk.

3. Terdiri atas kelompok-kelompok fungsional yang heterogen.

4. Mengemban fungsi umum.

5. Memiliki kebudayaan yang sama. ${ }^{21}$

Jika objeknya adalah masyarakat Muslim, tentu dimensinya sangat luar dan heterogen. Untuk wilayah Indonesia saja sudah demikian heterogen apalagi berbicara masyarakat muslim di dunia. Masyarakat Muslim masa lalu maupun Muslim masa sekarang. Beda dimensi waktu beda pula karakter masyarakatnya.

Untuk memahami lebih mendalam tentang karakteristik masyarakat Muslim yang ada di Palu, baik dalam lingkup yang luas maupun sempit, maka pendekatan sosiologis menjadi salah satu alternatif yang dapat digunakan untuk mengkaji terutama dalam hal fenomena keberagamaan maupun bentuk-bentuk interaksi sosial lainnya dalam masyarakat tersebut.

\section{b. Masyarakat Muslim Kota Palu}

Ajaran Islam yang masuk dan berkembang di Lembah Palu, sesuai dengan Proto Indonesia, yang tidak mengalami resistensi. Para bangsawan dan rakyatnya menerima Islam dengan sembari sebagai alat pemersatu di antara kelompok-kelompok masyarakat lainnya. Para pembawa Islam (da'i) memberi penghormatan kepada raja-raja yang ditemui di Nusantara. Bukti penghormatan itu berupa pemberian gelar

\footnotetext{
${ }^{21}$ Ibid, $75-77$
} 
Samsinas, Implementasi Islam Ina-ina Pedagang....

"sultan", yang menandai adanya legitimasi kerajaan di bawah Daulah Khilafah Turki Usmani. ${ }^{22}$

Di Lembah Palu, terdapat beberapa raja yang mendukung dan membantu penyebaran dan pengembangan agama Islam, antara lain, Raja Kabonene Pue Njidi pada tahun 1650, Raja Palu Pue Nggari, Raja Bangga Pue Bongo, hingga Raja Palu bernama Djanggola yang menerima kedatangan Sayyid Idrus bin Salim Aldjufri pada tahun 1930. ${ }^{23}$

Kehadiran Sayid Idrus mampu melakukan terobosan dan perubahan-perubahan dalam masyarakat secara signifikan. Sehingga dalam kurun waktu 39 tahun mampu menyebarluaskan dakwahnya diberbagai daerah di Sulawesi Tengah dan sekitarnya dengan membangun sekolah madrasah sebanyak 420 buah. Madrasah-madrasah ini sebahagian berada di Palu dan sekitarnya, serta Sulawesi Tengah pada umumnya. Sebahagian lagi Sulawesi Utara, Sulawesi Tenggara, Sulawesi Selatan, Irian Jaya, Maluku dan Kalimantan Timur. ${ }^{24}$

Melalui Sayid Idrus, Islam dianut masyarakat yang kemudian secara implisit-praktis mengubah sosial budaya masyarakat Palu (yang sebelumnya masih menjadi wilayah Donggala) disaat yang bersamaan Lembah Palu juga didatangi turis lokal seperti suku bugis, makasar, manado, jawa, maluku, kalimantan dan sumatera yang kemudian berdomisili dilembah Palu.

\footnotetext{
${ }^{22}$ Nasaruddin Umar, "Proto Indonesia", Jurnal Nasional, (Jakarta: PT Nusa Pradana, 16 Desember, 2011), 1.

${ }^{23}$ Syamsuri, Sejarah Dakwah di Lembah Palu, Jurnal Al-Mishbah Vol. 11 No. 1 Tahun 2015, (Komunitas Dosen Ilmu Dakwah dan Komunikasi IAIN Palu, 2015), 145.

${ }^{24}$ Mahmud Samsu As., Ulama Pembawa Islam di Indonesia dan Sekitarnya, (Jakarta: Lentera, 1996), 131.
} 
Selain itu pula, pendatang dari luar nusantara seperti India, Pakistan, Arab dan China juga mewarnai kehidupan sosial budaya Masyarakat Palu yang kemudian turut mendukung terbentuknya masyarakat Muslim Kota Palu, sebab mayoritas pendatang tersebut merupakan masyarakat beragama Islam dengan latarbelakang ideologi Islam yang khas pula, sehingga menjadikan masyarakat Muslim kota Palu dengan karakter sosial budaya yang beragam dan unik.

Mayoritas pendatang umumnya adalah pedagang-yang kemudian menjadi mitra kompetisi pribumi dari sektor ekonomi dan pasar, yang semakin lama persaingan itu nampak dimenangkan oleh para pendatang, sehingga pribumi Palu (suku kaili) secara perlahan mengambil lahan sebagai pedagang pasar di area pinggiran dan menjadi pedagang keliling seperti yang dilakukan ina-ina pedagang keliling, untuk menjual hasil pertanian ina-ina.

Dengan demikian tidak sedikit, masyarakat Muslim Palu (pribumi) merambah wilayah lain diluar ekonomi dan pasar. Ina-ina banyak mencari peluang dan berkompetisi di ranah administrasi pemerintahan dan pendidikan. Banyak pejabat lokal diduduki oleh muslim kaili, termasuk pejabat Kecamatan dan Kelurahan atau desa.

Masyarakat Muslim kaili juga sangat membuka diri untuk menikah dan beranak pinang dengan pendatang dari suku bangsa lain, sehingga kemudian banyak diantara masyarakat muslim Palu dan atau Kecamatan Palu Barat mengatakan "saya orang kaili walau nenek saya orang bugis" demikian juga kata-kata yang dikeluarkan oleh ina-ina yang menikah dengan suku lainnya. Sehingga tidak ada alasan untuk saling bermusuhan. 
Samsinas, Implementasi Islam Ina-ina Pedagang....

Namun demikian, ini merupakan potensi kedinamikaan dan kebhinnekaan yang harus terus dipertahankan dari generasi ke generasi sehingga tercipta Negara Kesatuan Republik Indonesia yang "gemah ripah loh jinawi toto tentrom kerto raharjo" yang ditopang oleh prinsip Kota Palu "rasa risi roso" (saling memahami, saling membantu dan saling menguatkan), sehingga nampak masyarakat Muslim Kota Palu atau kecamatan Palu Barat dan Kabupaten lain yang ada disekitar Kota Palu seperti Kabupaten Donggala dan Kabupaten Sigi tetap tenteram dan menjaga keharmonisan dalam bingkai NKRI.

\section{Hasil Penelitian dan Pembahasan}

1. Kehidupan Sosial-ekonomi ina-ina Sebagai Pedagang Keliling

Pada umumnya ina-ina pedagang keliling yang datang jualan di kecamatan Palu Barat berasal dari Desa Tipo Kecamatan Ulujadi Kota Palu, Desa Loli Kabupaten Donggala dan Desa Kanuna Kabupaten Sigi. Ketiga desa tersebut sangat berdekatan dengan kecamatan Palu Barat, oleh karena itu, ina-ina menjadikan kecamatan Palu Barat sebagai wilayah jualan ina-ina. Dari segi sosiologi Islam, ketiga desa dari tiga kabupaten/kota ini memiliki struktur dan karakter sosial budaya yang relatif sama terutama khusus yang terkait dengan ina-ina pedagang keliling.

Ina-ina pedagang keliling menjalani kegiatan dagangnya dengan berjalan kaki keliling jalan-jalan dalam kecamatan Palu Barat dari pagi sampai sore hari dengan barang dagangan antara lain; pisang, kacang kulit, ubi jalar dan ikan. Barang-barang dagangan seperti pisang, kacang kulit dan ubi jalar umumnya hasil panen dari lahan kebun sendiri dan 
kadang-kadang tadah dari orang lain dengan harga beli dan mengambil keuntungan dari harga jual. Sedangkan ikan umumnya ina-ina beli dari hasil tangkapan nelayan, ina-ina beli dan mendapat untung dari harga jualnya.

Hasil jualannya untuk memenuhi kebutuhan keluarga, baik untuk makan sehari-hari, biaya sekolah anak-anak, biaya pengobatan, dan kebutuhan lain keluarga. Pada prinsipnya ina-ina melakukan profesi jadi pedagang keliling sebagai bentuk tanggung jawab dan kepedulian terhadap keluarga. Ina-ina enggan meminta-minta iba dari orang lain sehingga selalu berupaya semaksimal mungkin bekerja keras untuk memenuhi kebutuhan keluarga meski dengan hasil yang tidak banyak dalam seharinya.

2. Implementasi Islam ina-ina pedagang keliling dalam analisis sosiologi Islam.

Dalam kaitannya dengan kegiatan ekonomi ina-ina, memberi warna tersendiri terhadap keberagamaannya, dimana secara prinsipil sebagai muslim ina-ina kokoh berkeyakinan percaya pada 6 rukun iman dan 5 rukun Islam dengan konsekwensi harus dijalani, namun dalam kegiatan ekonominya yang sulit menyebabkan tidak terlaksana keberagamaan secara normal, dimana pada saat jualan keliling ina-ina tidak melaksanakan sholat dhuhur dan ashar bahkan kadang-kadang juga tidak sholat maghrib.

Namun ina-ina tidak sholat karena beberapa alasan;

a. Pakaian dan badan keringatan (kotor)

Ina-ina tidak sholat saat badan kotor sebagai bentuk penghargaan terhadap Tuhan bahwa tidak boleh berhadapan dengan Tuhan jika 
Samsinas, Implementasi Islam Ina-ina Pedagang....

hamba dalam keadaan kotor atau hamba harus dalam keadaan bersih/ bersuci.

b. Ina-ina berkeyakinan bahwa berhadapan dengan Tuhan itu harus dalam keadaan khusu', sedang saat jualan ina-ina merasa sulit khusu'

c. Ina-ina berkeyakinan bahwa berhadapan dengan Tuhan harus dalam keadaan tenang atau tidak terburu-buru.

Sedangkan kondisi ketika jualan keliling itu ina-ina dalam keadaan tidak bersih karena keringatan, tidak khusuk karena memikirkan jualan dan tidak tenang karena harus buru-buru bekerja mencari nafkah. Meski demikian, walau tidak sholat pada saat mendengar azan ina-ina tetap dalam kondisi ingat kepada Allah, menjawab azan dan sadar akan kewajiban sholat dan melakukannya secara batin.

Dalam keseharian kegiatan sosial keagamaan ina-ina sama juga dengan masyarakat lainnya. Jika dirumah ina-ina tetap sholat lima waktu, mengaji, mengajarkan anak-anak sholat dan ngaji, terlibat dalam kegiatan-kegiatan sosial keagamaan seperti maulid, hari raya, hajatan masyarakat/tetangga dan turut telibat dalam kegiatan gotong royong yang diadakan oleh pemerintah desa.

Secara sosiologi Islam, ina-ina pedagang keliling merupakan bagian dari masyarakat muslim yang ada didesanya masing-masing, turut tanggung jawab dan peduli terhadap keluarga dan masyarakat sesuai kemampuan yang ada, turut menjadi bagian dalam menciptakan keharmonisan sosial dan tidak menjadi bagian yang menimbulkan masalah sosial. Meski secara ekonomi ina-ina ini termasuk kelompok ekonomi lemah, namun ina-ina tidak ingin menjadi bagian yang menjadi beban pemerintah dan masyarakat lainnya. Sebisa mungkin, ina-ina 
betul-betul menunjukkan keberdayaan ina-ina untuk memenuhi kebutuhan keluarga.

Dan dalam pada itu, ina-ina menjadikan komitmen kebaragamaannya sebagai dasar kekuatan dalam bertahan hidup (survive), menjalani kehidupan yang positif untuk masa depan kelurga khususnya anak-anak ina-ina, dan untuk menjalin hubungan (interaction) dengan keluarga dan masyarakat terutama usaha dan kerja keras ina-ina sebagai wujud kepasrahan pada takdir ilahi, bahwa tidak ada cobaan yang tiada ada jalan keluarnya. Bahwa ia diberi kehidupan seperti apa yang ia jalani bersama keluarganya adalah amanah dan dianggap mampu dijalani olehnya.

Ada beberapa faktor yang mempengaruhi kehidupan beragama ina-ina pedagang keliling yang ada di desa Tipo, Loli dan Kanuna, yakni faktor ekonomi, sosial budaya, pendidikan, politik dan agama. Faktorfaktor inilah yang turut menentukan bagamana keberagamaan ina-ina sehingga nampak seperti apa yang tertulis dalam laporan penelitian ini.

3. Diskusi tentang Implementasi Islam ina-ina dalam kehidupan sosial

Menganalisis keberagamaan ina-ina pedagang keliling bahwa fungsi agama nampak dikehidupan sehari-hari dimana agama (Islam) menjadi sumber kehidupan baik secara individu maupun keluarganya dengan memulai aktifitas kesehariannya dengan sholat subuh, membangun rasa percaya diri dan optimisme dalam menjalani seluruh aktifitasnya, tetap kembali melaksanakan ibadah disore hingga malam hari meski tidak melaksanakan disiang hari saat berjualan keliling. 
Samsinas, Implementasi Islam Ina-ina Pedagang....

Ina-ina juga menyadari prosedur hubungan manusia dengan Tuhan, bahwa dalam menghadap Tuhan tidak boleh asal, tetapi harus peduli dalam soal kebersihan dan kekhusukan dalam beribadah sehingga mancapai rasa keberagamaan yakni menemukan kebenaran dan kemudahan (solution) ketika menghadapi masalah dan kesulitan.

Dalam keberagamaan ina-ina dapat membangun kebersamaan dalam keluarga dan kehidupan sosial, baik melalui zakat, sedekah, saling berbagi saat lebaran (idul fitri dan idul adha) dan saling mendukung saat hajatan keluarga dan tetangga. Semangat keberagamaan juga menjadi dasar membangun rasa perjuangan bersama dalam membangun keluarga dan cita-cita masa depan, kemandirian dan kesungguhan berusaha dan bekerja, membangun komitmen bahwa meminta atau bergantung pada orang lain dilarang oleh agama. Demikian pula dalam membangun kesadaran akan kemandirian pada keluarga seperti yang dilakukan oleh Yadiah dan Zawiah terhadap anak-anaknya. Spirit agama menjadi fondasi dan pedoman dalam membangun masa depan keluarga.

Dengan demikian, ina-ina menjadikan agama sebagai syarat prinsip benar dan salah, misalnya dalam urusan dagang, ina-ina hanya mengambil untung sesuai harga jual. Menjual mengelilingi jalan-jalan dan perkampungan diwilayah kecamatan Palu Barat dan sekitarnya sebagai usaha mencari nafkah kelurga, berprinsip makan dan membesarkan anakanak dengan hasil keringat sendiri lebih berberkah atau lebih baik dari pada meminta-minta, atau mungkin mencuri milik orang lain. Sehubungan dengan itu, dalam pengamatan penulis, bahwa meski penghasilan dalam sehari kecil atau tidak sebanding dengan energi yang dikeluarkan, namun ina-ina merasa bahagia dan bersyukur dengan hasil 
yang diperoleh. Bagi ina-ina, itulah rezeki dari Allah yang diterima pada hari itu.

Atas dasar inilah, dapat dinilai bahwa ina-ina dan keluarga menjalani kehidupan dengan demikian sulitnya dengan justru menikmatinya, sebagai etetika batiniah maupun laihiriah. Sesulit apapun kehidupan yang ina-ina jalani ina-ina pasrahkan pada Tuhan, sebagaimana keyakinan umat Islam bahwa Tuhan memberi cobaan sesuai kemampuan hambanya, jadi apapun bentuk kesulitan hidup inaina anggap sesuai kesanggupan jiwa ina-ina menjalaninya. Sehingga tidak nampak keluhan dan rasa atau sikap putus asa diwajahnya baik terhadap anggota keluarga maupun orang lain. Dan sholat menjadi media menunpahkan kepasraan dan ekpektasi kepada Tuhan dengan demikian beban-beban yang dihadapi terasa ringan. Ibarat sholat atau bersandar kepada Tuhan adalah saat rekreasi batiniah. Meski ini sifatnya psikologi tetapi justru menjadi spirit positif bagi hubungan sosial ina-ina dengan keluarganya maupun dengan masyarakat disekitar.

Implementasi keberagamaan ina-ina ini, akan menunjukkan hakekat fungsi agama (Islam) dalam kehidupan ina-ina sehari-hari, baik sebagai individu maupun sebagai bahagian dari kelompok keluarga dan lingkungan sosial atau masyarakat secara sosial. Baik dalam interaksi sosial maupun dalam membangun solidaritas sosial, baik dalam urusan sosial, pendidikan maupun dalam kaitannya dengan urusan ekonomi keluarga.

Sebagaimana disebutkan dalam bab sebelumnya (bab II), ada lima dimensi Agama dalam diri manusia yakni dimensi keyakinan (ideology), dimensi peribadatan dan praktek keagamaan (ritualistic), 
Samsinas, Implementasi Islam Ina-ina Pedagang....

dimensi penghayatan (experensia), dimensi pengamalan (konsekwensial), dan dimensi pengetahuan agama (intelectual).

Terkait dengan penelitian ini, salah satu dimensi yang tidak disebutkan diatas adalah dimensi perilaku sosial keagamaan yakni perilaku yang didasarkan agama. Namun pada aspek atau dimensi pengamalan (konsekwensial) adalah konsekwensi keyakinan berupa pengamalan perintah atau ajaran Tuhan yang terpatron, baik terkait hubungan transendental dengan Tuhan maupun dengan sesama manusia baik dalam kaitan dengan pemenuhan kebutuhan rohani maupun kebutuhan jasmani atau duniawi. Efek kemantapan keberagamaan menumbuhkan etos kerja, kepedulian sosial, dan hubungan interpersonal seperti tanggung jawab memenuhi kebutuhan keluarga dengan amanah dan kemuliaan.

Dalam Islam, keluasan keberagamaan menunjukkan kedalaman penghayatan atau kekuatan aqidah seseorang, kedalaman penghayatan dapat melahirkan intensitas dan konsistensi ritual pengamalan keagamaannya, kedalaman penghayatan dan konsistensi pengamalan agama akan berpengaruh pada sikap hidup dan hubungan sosial seorang muslim separti memiliki rasa tanggung jawab dan kepedulian terhadap keluarga dan masyarakat disekitarnya.

Ina-ina pedagang keliling memiliki rasa tanggung jawab itu terhadap keluarga, seperti tiga orang ina-ina yang menjadi obyek penelitian ini adalah membesarkan, menyekolahkan dan berusahan semaksimal mungkin membiayai seluruh kebutuhan anak-anak dan atau keluarganya, yakni suatu bentuk nilai dari hasil pengamalan agama (Islam) yang dianutnya. 
Selain itu ina-ina memiliki rasa solidaritas sosial dan toleransi yang sangat tinggi terhadap perbedaan yang ada dalam masyarakat sekitarnya. Ina tetap berperilaku sebagai bahagian dari masyarakat yang harus turut menjaga harmonisasi sosial dan solid menjaga harmonisasi itu sehingga tidak menimbulkan ketidakteraturan sosial (social disorder) termasuk menjaga dirinya untuk tidak menimbulkan masalah sosial (social problem).

Kontribusi dalam menciptakan keharmonisasn sosial dapat dilihat dalam kegiatan gotong royong membersihkan lingkungan disekitar rumah masing-masing yang sesekali diadakan atas perintah kepala desa dan atau RT, turut pula menyumbangkan konsumsi saat kegiatan tersebut sesuai kemampuan masing-masing-sebuah bentuk implementasi nilai Islam tentang patuh pada perintah Allah, Rasul dan Umara' (pemimpin).

Dalam kegiatan keagammaan juga ina-ina juga turut andil seperti memberi konsumsi buka puasa, atau menyumbang tenaga dalam pembangunan masjid seperti mengangkat pasir, kerikil dan atau konsumsi bagi para pekerja pembangunan masjid. Pada saat maulid nabi, ina-ina juga turut meramaikan untuk menyediakan makanan yang terdiri nasi ketan (sokko) dan telur sebagai baraka (makanan yang dido'akan) yang akan dibagikan ke masyarakat setelah upacara maulid selesai.

Pada saat suasana lebaran idul fitri dan idul adha, ina-ina bersama keluarga biasa berkeliling berziarah, berma'af-ma'afan ke sesama muslim maupun non muslim, dikalangan keluarga maupun handai taulan, sehingga rasa kebersamaan dan kekeluargaan tumbuh dimasyarakat desa Tipo, Loli maupun Kanuna dimana ina-ina berada. Suasana yang begitu mudah untuk saling memberi, baik berupa memberi ma'af, kasih sayang, maupun makanan dan lainnya, Merasakan bahagia 
Samsinas, Implementasi Islam Ina-ina Pedagang....

dengan berbagi, memaafkan, mensyukuri dan jiwa-jiwa terbuka untuk menerima dan menyayangi satu dengan yang lain bahkan tak ada rasa risih untuk bertemu dan bersalaman dengan orang-orang yang berbeda usia, agama, pendidikan, pekerjaan, ekonomi dan lain sebagainya, menunjukkan manfaat hari raya lebaran menjadi momen yang indah untuk memperbaiki hubungan sosial ina-ina dan keluarga serta masyarakat bahkan termasuk dengan konsumen atau pelanggan ina-ina yang ada di kecamatan Palu Barat Kota Palu.

Sebelum hari $\mathrm{H}$ lebaran, biasanya ina-ina tidak lagi ke Palu Barat untuk menjual, tetapi sebahagian dari ina-ina ada yang meminta hagala (sedekah) yang lazim dikeluarkan masyarakat muslim menjelang lebaran sebagai bentuk rasa syukur atas rezeki yang diberikan Allah selama setahun sebelumnya. Ina-ina yang punya langganan biasa datang kelangganannya, tapi bagi ina-ina lain yang bukan pedagang keliling dan tidak punya pelanggan turut meminta sedekah pada masyarakat yang dianggapnya mampu mengeluarkan sedekah. Ina-ina bahkan dengan anak-anaknya mengetuk setiap rumah yang ia lewati dengan harapan diberi sedekah oleh empunya rumah. Kegiatan jelang lebaran dengan meminta hagala menjadi tradisi dikalangan ina-ina, dan oleh karena itu masyarakat yang didatangi juga memakluminya. Tetapi seiring berjalannya waktu, makin sedikit ina-ina yang datang meminta hagala setiap menjelang lebaran.

Secara sosial budaya, ina-ina pedagang keliling di tiga desa (Tipo, Loli dan Kanuna) ini lebih terpola oleh pola sosial budaya yang telah berlaku, sehingga tidak ada yang saling bertentangan. Hanya satu hal yang tidak umum adalah ina-ina tidak sholat (secara fisik) jika sedang bekerja atau menjual keliling didaerah yang jauh dari rumahnya. Bagi 
masyarakat umum lainnya yang berada diluar desa ina-ina hal itu dianggap perilaku keagamaan yang menyimpang menganggap aneh bahkan dianggap tak beragama. Karena publik melihat hanya saat ina-ina berjualan keliling dan secara terang-terangan pula diakui oleh ina-ina sendiri.

Berbeda penilaian sekilas dari masyarakat luar, berbeda pula bagi ina yang faham pola pikir dan perilaku keberagamaan ina-ina. Bahkan menjadi hal biasa dikalangan ina-ina, pada prinsipnya ina-ina tidak sholat bukan karena meninggalkan agama atau perintah Tuhan tetapi karena ina-ina tidak ingin bermain-main dalam berhubungan dengan Tuhan yang menuntut para hamba harus dalam keadaan suci, khusu' dan tenang menjalankannya. Hal lainnya tetap sama dengan masyarakat Muslim lainnya, menjalankan kewajiban agama dan memiliki tanggung jawab sosial terhadap keluarga dan masyarakat.

\section{Penutup}

\section{Simpulan}

Ina-ina pedagang keliling adalah sekelompok perempuan yang menjalani pekerjaan dengan berdagang keliling beberapa barang dengan cara memikul dan berjalan kaki diwilayah kecamatan Palu Barat. Ina-ina dalam penelitian ini berasal dari desa Kanuna kecamatan Marawola kabupaten Sigi, desa Tipo kecamatan Ulujadi Kota Palu dan desa Loli Kabupaten Donggala. Ketiga desa ini sangat berdekatan dengan kecamatan Palu Barat dan karena alasan kedekatan geografis inilah sehingga ina-ina dari kabupaten tetangga memilih berjualan keliling di kecamatan Palu Barat. 
Samsinas, Implementasi Islam Ina-ina Pedagang....

Kegiatan berdagang ini merupakan pekerjaan utama ina-ina dalam rangka mencari nafkah keluarga, baik untuk kebutuhan sehari-hari maupun biaya sekolah anak-anak atau yang lainnya. Kegiatan berdagang keliling ini berlangsung selama satu hari full setiap harinya akibatnya mempengaruhi kehidupan beragama ina-ina. Sehingga nampak berbeda dengan masyarakat pada umumnya. Meski demikian secara prinsipil terkait pemahaman beragama tidak ada yang menyimpang kecuali secara hukum/fiqh, karena meninggalkan sholat pada saat mereka jualan. Tetapi ketika tidak sedang jualan ina-ina tetap menjalani sholat lima waktu sebagaimana biasa.

Dalam kehidupan sosialnya, ina-ina pedagang keliling memiliki jiwa sosial dan kepedulian terhada keluraga dan masyarakat. Menjual keliling itu dipilihnya sebagai salah satu tanggungjawabnya terhadap keberlangsungan ekonomi keluarga. Ina-ina juga sangat respon terhadap masalah sosial dimasyarakat sehingga tetap terlibat dalam menyelesaikannya. Ina-ina juga turut berperan jika ada hajatan tetangga atau masyarakat sekitarnya demikian juga dalam kegiatan-kegiatan keagamaan sebagai bentuk kesadaran beragama dan hidup bermasyarakat.

2. Implikasi Penelitian

Berdasarkan hasil penelitian ini, dapat menjadi dasar analisis dan penentuan kebijakan dan program yang berorientasi pada pemberdayaan ekonomi umat atau masyarakat Islam khususnya ina-ina pedagang keliling yang ada di tiga desa tersebut, baik oleh legistatif dan eksekutif Kota Palu, Kabupaten Donggala maupun Kabupaten Sigi maupun oleh komponen masyarakat yang peduli terhadap masyarakat miskin seperti Lembaga Swadaya Masyarakat atau Non Government Organisation (NGO) lainnya. 
Menganalisis hasil penelitian ini, bahwa agama dapat menjadi fondasi kekuatan bagi kebertahanan hidup keluarga, menjadi dasar dalam pengamalan agama terkait tanggung jawab terhadap keluarga dan hubungan sosial di masyarakat yang heterogen serta ketaatan terhadap Allah, Rasul dan pemerintah.

\section{Daftar Pustaka}

Ancok, Djamauddin, Fuat Nashori Suroro, Psykologi Islam, Yogyakarta: Pustaka Pelajar, 1995

Ansari, Endang Saifuddin, Wawasan Islam, Cet. IV; Jakarta: Raja Grafindo Persada, 1993

Bahreisi, Hussein, Hadits Bukhari-Muslim, Surabaya : Karya Utama, tth

Hendropuspito, Sosiologi Sistemik, Yogyakarta: Kanisius, 1989

Kementerian Agama RI, Alquran dan Terjemahnya, Bandung: Fokus Media, 2010.

Kurniawan, Aris, http://www.gurupendidikan.com/3-pengertian-agamamenurut-para-ahli-keagamaan, diakses tanggal 20 September 2016

Poerwadarminta, Kamus Umum Bahasa Indonesia, Jakarta: Balai Pustaka, 1978

Robertson, Roland. Agama dalam Analisa dan Interpretasi Sosiologis, Diterjemahkan oleh Syaifuddin, Jakarta: Raja Grafindo Persada, 1993

Rahmat, Jalaluddin, Islam alternatef, Bandung : Mizan, 1986

Samsu As, Mahmud., Ulama Pembawa Islam di Indonesia dan Sekitarnya, (Jakarta: Lentera, 1996

Shadily, Hassan, Sosiologi Untuk Masyarakat Indonesia, Jakarta: Rineka Cipta, 1993Salim, Peter \& Yenny Salim, Kamus Bahasa Indonesia Kontemporer Jakarta: Modern English Press, 1991

Suprayogo, Imam \& Tabrani, Metodologi Penelitian Sosial Agama, Cet. I; Bandung: PT. Remaja Rosda Karya, 2001. 
Samsinas, Implementasi Islam Ina-ina Pedagang....

Syamsuri, Sejarah Dakwah di Lembah Palu, Jurnal Al-Mishbah Vol. 11 No. 1 Tahun 2015, Komunitas Dosen Ilmu Dakwah dan Komunikasi IAIN Palu, 2015

Umar, Nasaruddin, "Proto Indonesia", Jurnal Nasional, (Jakarta: PT Nusa Pradana, 16 Desember, 2011.

https://capunktogel86.wordpress.com/arti-bahasa-kaili// diakses tanggal 6 Juni 2016

https://capunktogel86.wordpress.com/arti-bahasa-kaili// diakses tanggal 6 Juni 2016

https://id.wikipedia.org/wiki/Palu_Barat,_Palu, diakses tanggal 4 oktober 2016

https://palukota.bps.go.id/linkTabelStatis/view/id/226, diakses tanggal 4 oktober 2016 